\title{
Comparison between two sternum closing techniques by median sternotomy during open cardiac surgery
}

\author{
Kenan Abdurrahman Kara' ${ }^{1}$ Zafer Erk², Aytuğ Koçyiğit ${ }^{3}$, Şenol Gülmen ${ }^{4}$, \\ Ahmet Öcal $^{1}$, Hüseyin Okutan ${ }^{5}$
}

\footnotetext{
1) Hisar Intercontinental Hospital, Department of Cardiovascular surgery, M.D., Ümraniye, Istanbul, Turkey

2) Antalya Research and Tranining Hospital, Department of Cardiovascular surgery, M.D., Antalya, Turkey

3) Tekden Hospital, Department of Cardiovascular surgery, M.D., Denizli, Turkey

4) Süleyman Demirel University Hospital, Department of Cardiovascular surgery, M.D., Isparta, Turkey

${ }^{5)}$ Medicalpark Hospital, Department of Cardiovascular surgery, M.D., Antalya, Turkey
}

\begin{abstract}
Introduction: Recovery failures such as sternal dehiscence, sternal pain, sternal wound infections, osteomyelit and mediastinit can be seen after median sternotomy in coroner bypass surgery. In this study, two sternum band closure methods which we find more effective and secure than conventional sternal closure method, are compared.

Method: In this prospective study that compares two sternal band closure techniques, 114 patients are divided in two groups as Group $\mathrm{A}(\mathrm{n}=54)$ and Group $\mathrm{B}(\mathrm{n}=60)$. This research compares the results for sternal dehiscence, sternal wound infections, sternal pain and mediastinit in these patient groups between December 2011 and July 2012.
\end{abstract}

Results: Out of the two, a meaningful recovery is achieved in Group A compared to Group B ( $\mathrm{p}<0.05)$. No superficial woud infection, sternal dehiscence and mediastinit are found in patients of both band groups.

Conclusion: In this study, two different band closure techniques for sternotomy closure after the coroner bypass surgery are compared, and it is revealed that sternal pain index decreases meaningfully, compared to the other.

Key Words: Sternal band, sternal dehissence, sternotomy, pain index 


\section{Introduction}

Median sternotomy is the most frequently used incision in patients of open cardiac surgery. Following open cardiac surgery by median sternotomy, sternum is closed by surgical steel wires as whole layer. Potential post-operative sternal instability definition is dehiscence of both sternal parts due to cutting of sternal cortical layers by sternum closing wires with inappropriate movements of patient. This may result in conditions ranging from increased postoperative pain, sternal wound infection and mediastinitis associated with higher morbidity and mortality, prolonged hospital stay and increased treatment cost. ${ }^{(1-4)}$

Sternal bands used in our study are reported to prevent cutting of sternal cortex as tension on sternum is applied on larger and more balanced area, unlike to conventional sternal steel wires. ${ }^{(4-6)}$

The aim of this study to compare two different sternal band closing methods combined by conventional sternal closing method and to report the results.

\section{Patients and Method}

In our clinic, 114 patients (60 males, 54 females; mean age 65,095 years) underwent to open cardiac surgery between December 2011 and July -2012 were prospectively reviewed. Sternal closinmg was performed by Peninsula Sterna -Band® (L.L.C. Livonia MI. USA ) was used in 54 patients consisting first group (group A) and by Ethicon Sternum Band (Norderstedt, Germany) used in 60 patients consisting second group (group B).

Patients with pre-operative renal insufficiency, left ventricle dysfunction, patients receiving anticoagulants, those who have hemorrhagic disorder and those who received postoperative over two drains, were not included in the study. Preoperative demographic properties of patients are shown in Table 1.

Anesthetic medication and prophylaxis were identical in both groups. Following standard sterilization, operating area was covered by ioban 2 drape (3M Health Care, St Paul, MN, USA). Following median sternotomy, antegrade cold blood cardioplegia with intervals of

Table 1. Preoperative demographic properties.

\begin{tabular}{|l|c|c|c|}
\hline \multicolumn{1}{|c|}{ Group } & A & B & p value \\
\hline Patient number & 54 & 60 & NS \\
\hline Age (Years) & $64.96 \pm 9.88$ & $65.23 \pm 10.11$ & NS \\
\hline Weight (kg) & $75.16 \pm 12$. & $78.1 \pm 17.48$ & NS \\
\hline Height (cm) & $165.00 \pm 8.4$ & $166.45 \pm 9.25$ & NS \\
\hline BMI & $27.59 \pm 3.98$ & $28.12 \pm 5.35$ & NS \\
\hline COPD & $21(\% 38.9)$ & $28(\% 46.7)$ & NS \\
\hline DM & $20(\% 37.0)$ & $27(\% 45)$ & NS \\
\hline Obesity (BMI > 30) & $25(\% 46.3)$ & $23(\% 38.3)$ & NS \\
\hline Osteoporosis & $3(\% 5.6)$ & $9(\% 15)$ & NS \\
\hline Smaller Sternum & $7(\% 13)$ & $6(\% 10)$ & NS \\
\hline COPD: Chronic obstructive pulmonary disease; DM: Diabetes mellitus; BMI: Body mass index; NS: Non-significant.
\end{tabular}


20 minutes and continuous retrograde blood cardioplegia were used with standard cardiopulmonary bypass.

Retrosternal two sternal bands at intercostal spaces 3 and 4 and four standard 5/0 steel wires at intercostal spaces 1- 2- 5 and 6 were placed for sternal closing in Group A. In Group B, retrosternal sternal band at intercostal spaces 3 and five standard 5/0 steel wires at intercostal spaces 1-2- 4-5 and 6 were placed. Then cutaneous and subcutaneous tissues were closed standardly. Following post-operative hemodynamic stability, all patients were ex-tubed at hour 4 to 6 and pain index scoring was obtained following mobilization during post-operative intensive unit care. Pain index was obtained by using pain scoring method Visual Analogue Scale (VAS) to evaluate the effect of both bands on post-operative pain. Patients were verbally asked to

Table 2.

\begin{tabular}{|c|c|c|}
\hline & Group A & Group B \\
\hline On pump CABG & 45 & 52 \\
\hline Valve + CABG & 3 & 2 \\
\hline Off- pump CABG & 6 & 3 \\
\hline CABG: Coronary artery bypass graft & \\
\hline
\end{tabular}

rate the presence, frequency and severity of pain on the sternum by a scale of 1 to 10 . Pain index scoring was calculated by multiplying post-operative pain frequency by pain severity.

Statistical analysis was performed by SPSS 15.0 version for Windows (SPSS Inc., Chicago, Illınois, USA) software. T-Test, Pearson Chi-Square test and Mann-Whitney test were used for data analysis. Statistical data was expressed as mean \pm standard deviation and significance was considered as $\mathrm{p}<0.05$.

The study was approved by Süleyman Demirel University Faculty of Medicine Scientific Study Projects Consulting Coordinating Board by project number B.30.2.SDU.0.20.05.07-507/5077 on 27.12.2011 and board decision no. $27 / 6$.

\section{Results}

Pre-operative demographics were not statistically significantly different between two groups (Table 1). Surgery type of operated patients is shown on Table 2. When peri- and post-operative variables were evaluated, there was no statistical difference in respect of cardiopulmonary bypass time (CPB), aortic cross clamp time (ACC), DR drainage amount, the amount of blood utilized, administration of inotropes, drain removal

Table 3.

\begin{tabular}{|c|c|c|c|}
\hline & Group A ( $n=54)$ & Group B ( $n=60)$ & $\mathbf{P}$ \\
\hline CPB & $100.1 \pm 26$ & $103.5 \pm 30.2$ & NS \\
\hline ACC & $60.8 \pm 10.2$ & $63.6 \pm 7.0$ & NS \\
\hline Total drain (ml) & $850 \pm 330.5$ & $800 \pm 310.2$ & NS \\
\hline Drain removal (hour) & $44 \pm 4.1$ & $43 \pm 4.08$ & NS \\
\hline Superficial wound infection & - & - & - \\
\hline Mediastinitis & - & - & - \\
\hline Dehiscence & 2 & 1 & NS \\
\hline Discharge time (days) & 7 & 7 & NS \\
\hline Pain index & $6(\min 1-\max 48)$ & $4.00(\min .1-\max 63)$ & $p=0.011, P<0.05$ \\
\hline
\end{tabular}


time, superficial wound infection, mediastinitis, dehiscence and discharge time $(p>0.05)$, (Table 3$)$.

Mean pain index was $6.00(\min 1-\max 48)$ and 4.00 ( $\min 1-\max 63$ ) in Group A and Group B, respectively. Statistically significant difference was found between two groups in respect of pain index $(p=0.011)$.

\section{Discussion}

Complete closing of sternum following median sternotomy during open cardiac surgery, is a critical point in prevention of postoperative complications due to sternotomy. These complications include mainly dehiscence as well as a broad range of conditions such as pain, superficial wound infection and mediastinitis. Currently several sternal closing methods were described to prevent these complications. ${ }^{(4)}$ Therefore, in our study we compared two different sternal bands used for sternal closing.

In patients with sternotomy, sternal dehiscence is the most frequent complication and the rate is $0.3 \%$ to $5 \%$. This is a mechanical problem associated with certain factors such as lack of attention of patient to protect the sternum post-operatively, COPD, obesity, osteoporosis, use of bilateral mammarian arteries, renal insufficiency, administration of steroids and re-operation. ${ }^{(4)}$ The incidence of sternal wound infection is $0.4-5 \%$ and it is closely associated with dehiscence. ${ }^{(10)}$

Figure 1.

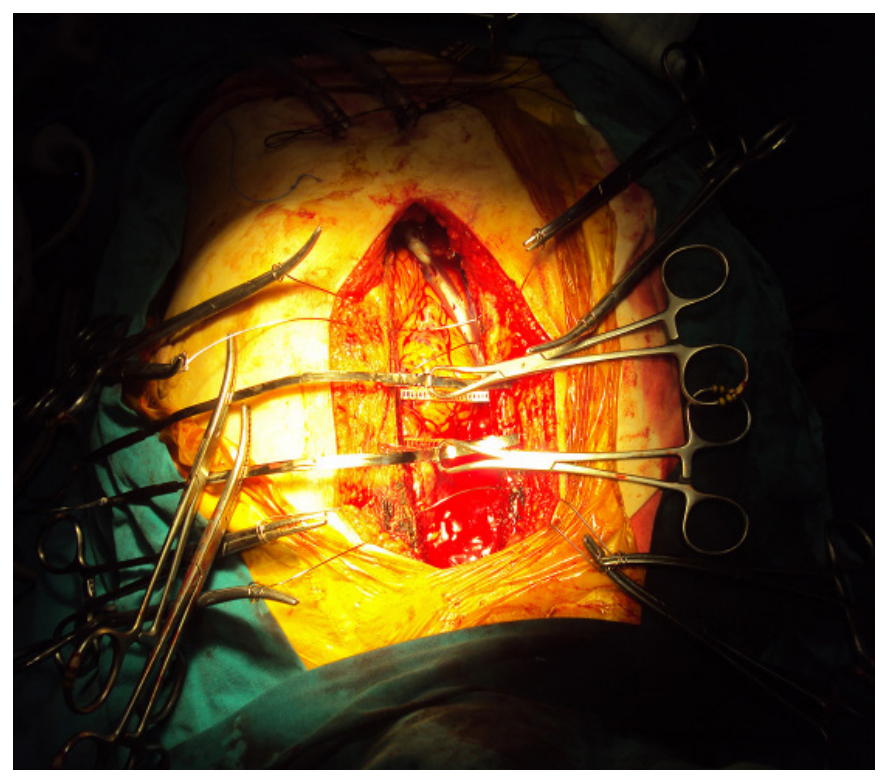

Closing of sternum is an important factor for sternal dehiscence. During sternal closing done by conventional approach using steel wires $5 / 0$, bone cortex erosion, fracture and consequently sternal dehiscence can occur due to compression of steel wires. Sternal dehiscence may lead to respiratory dysfunction, infection, increased pain and re-exploration. ${ }^{(16)}$ Use of sternal band, especially retrosternal application at intercostal space 3 and 4 to transversely surrounding whole sternum, is the most important mechanism to reduce development of sternal dehiscence with its 6 times larger surface than steel wires and thus providing equal loading on sternum. In our study, sternal dehiscence and sternal wound infection were not detected in both groups.

Postoperative pain is an acute pain gradually reducing by tissue healing accompanied also by inflammatory process. ${ }^{(6)}$ Indeed, acute pain is a complex sensation besides its simple perceptional character. Difference in pain perception may be due to central process, fear, anxiety, depression and previous experience on pain perception. Certain patients may not describe the pain due to their higher pain tolerance or their introvert pain handling methods. Difference in pain perception of patients may be also due to post-operative analgesic administration methods. However, $30 \%$ of surgery patients don't require postoperative analgesics. ${ }^{(7)}$ In a prospective clinical study, localization, distribution

Figure 2.

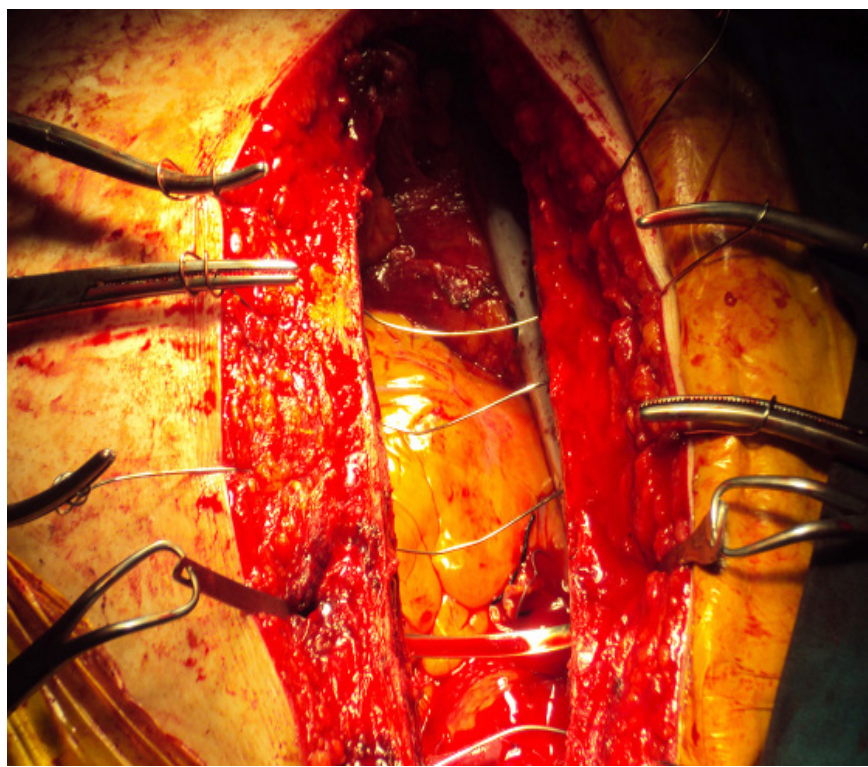


and severity of postoperative pain were evaluated in consecutive 200 patients with cardiac surgery by median sternotomy. ${ }^{(8)}$ Investigators determined the highest pain intensity on day 1 and lowest intensity on day 3. Although pain distribution was not different during post-operative period, there was difference in its localization. $^{(9,15)}$ Another factor affecting the pain severity is the age of patient. Young patients reported more severe

Figure 3.

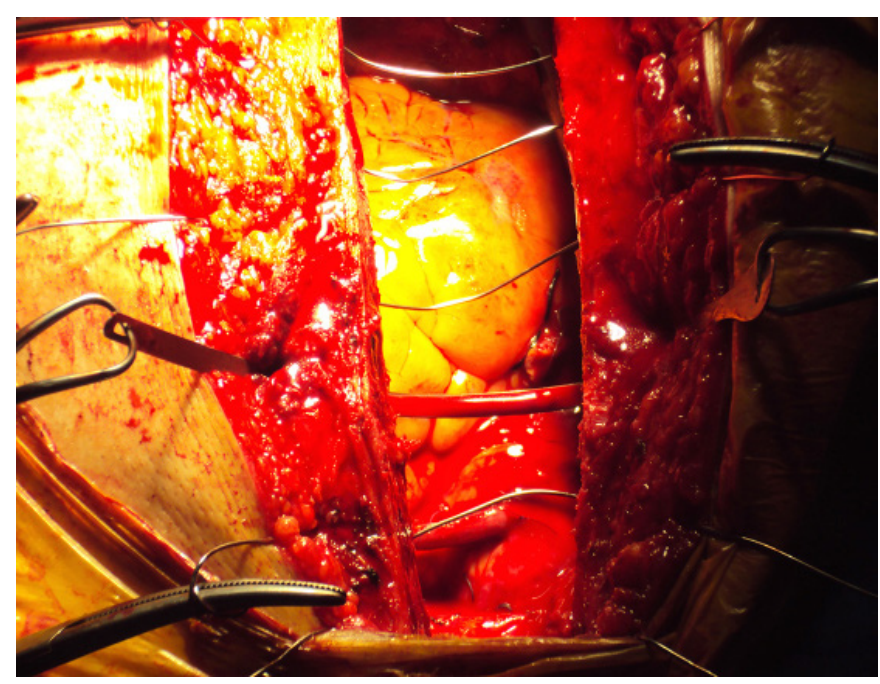

pain than patients over 60 years. ${ }^{(8,11)}$

Previous studies comparing sternal band and conventional sternal closing also showed that usage of sternal band was associated with decreased pain and this was explained by reduced development of sternal dehiscence. However, in our study, we determined a difference between different methods of sternal bands in respect of pain development. When two groups of our study were compared, there was significant reduction in post-operative pain development in Group B compared to Group A. At this point, we consider that reduced compression of band method on a smaller bone cortex area only at intercostal space 3 in Group B compared to band method of Group A, could explain lower pain.

However, we think that the limited number of studies on pain in cardiac surgery and multifactorial nature of pain are limitations of our study. Although our study is prospective and including low number of patients, we conclude that larger studies will provide more guidance by including psychological and anatomic-physical parameters such as difference in physical load on bone structure by the material utilized. 


\section{References}

1. A.Rahman,O Burma.The effect of coronary artery bypass grafting with Cardiopulmonary bypass and beating heart technique on cardiac performance Turkish J Thorac Cardiovasc Surg 2001;9:68-73

2. H.Ekin,V.Kutay Tek ve İki Damar Hastalarında Çalışan Kalpte ve Kardiyopulmoner Bypass ile Yapılan Myokardiyal Revaskülarizasyonların Karşılaştırılması Van Tıp Dergisi: 2004;11 (3):92-97

3. Cameron A, Davis KB, Green G, Schaff HV. Coronary bypass surgery with internal-thoracic-artery grafts-effects on survival over a 15 -year period.N Engl J Med 1996;334:216-9.

4. Friedrich-Christian Riess,1 Nizar Awwad,1 Bettina Hoffmann. A Steel Band in Addition to 8 Wire Cerclages Reduces the Risk of Sternal Dehiscence after Median Sternotomy. The Heart Surgery Forum 7 (6), 2004 [Epub September 2004]

5. Wewers ME, Lowe NK. A critical review of visual analogue scales in the measurement of clinical phenomena. Research in Nursing \& Health 1990;13: 227-236,

6. Uyar M. Postoperatif ağrılı hastanın değerlendirilmesi ve ağrı ölçümü. Yücel A ed. Postoperatif analjezi 1. basım. İstanbul: Mavimer Matbacılık Yayınc1lık Ltd. Şti. 2004; 27-36.

7. Rawal N. Postoperatif Ağrının Psikolojik Etkileri Editör: Erdine S. Ağrı. Nobel Tip Kitabevleri 1.baskı. 2000; 124-125.

8. Mueller XM, Tinguely F, Tevaearai HT ve ark. Pain location, distribu- tion and intensity after cardiac surgery. Chest 2000; 118: 391-6.

9. Moore R, Follette DM, Berkoff HA. Poststernotomy fractures and pain management in open cardiac surgery. Chest 1994; 106: 1339-42.

10. Blanchard A, Hurni M, Ruchat P, et al: Incidence of deep and superficial sternal infection after open heart surgery: A ten years retrospective study from 1981 to 1991. Eur J Cardiothorac Surg 1995; 9: 153-8.

11. Farinas MC, Peralta FG, Bernal JM, et al: Supurative mediastinitis after open heart surgery: A case-control study covering a seven year period in Santander, Spain. Clin Infect Dis 1995; 20: 272-6.

12. He GW, Ryan WH, Acuff TE, et al: Risk factors for operative mortality and sternal wound infection in bilateral internal mammary artery grafting. J Thorac Cardiovasc Surg 1994; 107: 196-9.

13. Kluytmans JAJW, Mouton JW, Ijzermann EPF, et al: Nasal carriage of staphylococcus aureus as a major risk factor for wound infections after cardiac surgery. J Infect Disc 1995; 171: 216-9.

14. Jurkiewicz MJ, Bostwick J, Hester TR, Bishop JB, Craver J. Infected median sternotomy wound. Ann. Surg. 1980; 191(6):738-43.

15. Catarino PA, Chamberlain MH, Wright NC, Black E. High-Pressure suction drainage via a polyurethane foam in the management of poststernotomy mediastinitis. Ann. Thorac Surg. 2000; 70: 1891-5.

16. Robiscek F, Fokin A, Cook J, Bhatia D. Sternal Instability After Midline Sternotomy. Thorac Cardiov Surg. 2000; 48 (4): 1-8.
Received: 16/05/2017

Accepted: 04/09/2017

Published: 15/09/2017

Disclosure and conflicts of interest:

The authors declare no conflict of interest.

Corresponding author:

Kenan Abdurrahman Kara

Mail: kenankaradoc@gmail.com 